\title{
Evolution of the water chemistry of Lake Orta after liming
}

\author{
Alcide CALDERONI* and Gabriele A.TARTARI \\ C.N.R. Istituto Italiano di Idrobiologia. Largo Tonolli 50, I 28922 Verbania Pallanza, Italy \\ *e-mail corresponding author: a.calderoni@iii.to.cnr.it
}

\begin{abstract}
Since 1963 Lake Orta has been an emblematic case of industrial pollution by heavy metals and acidifying compounds (ammonium sulphate), to the extent that up to 1989 it was the largest acidified deep lake in the world. The low pH values of between 3.9 and 4.4 helped to keep high the levels of toxic compounds in solution, such as copper, aluminium, zinc and nickel. The liming performed in 1989-1990 brought the $\mathrm{pH}$ back to neutral values, determining the precipitation of the metals and the recovery of normal chemical conditions. The main results of researches conducted continuously on the lake water chemistry from 1988 to March 2000 are as follows. The whole water mass has been completely neutralised since the beginning of 1991; pH subsequently rose until in 1999-2000 it reached the values (6.7-6.9 units) of the years when the lake was in a natural condition. The alkaline reserve showed a continuous increase after the lake water was neutralised, until March 2000, when total alkalinity values levelled off at 0.19 meq $l^{-1}$. The increase in $\mathrm{pH}$ has allowed a full recovery of nitrification processes; in fact, during the liming period the concentration of ammonium was drastically reduced, by over 80\%; ammonium has been practically absent since the end of 1992, and it may be affirmed that the primary cause of the acidification of the lake has been completely removed. The nitrate content in the lake has almost halved compared with the mean concentrations measured before the liming; in March 2000 mean values of $2.0 \mathrm{mg} \mathrm{N}^{-1}$ were measured, and it is likely that these values will fall further in the next few years, to below $1.5 \mathrm{mg} \mathrm{N}^{-1}$. The concentrations of toxic metals have shown a progressive reduction, to the extent that in 1999 the content of copper and aluminium was close to zero in the whole water mass. The situation of Lake Orta has therefore improved enormously, and is now very similar to the original condition of the lake before it was polluted. However, this situation cannot be regarded as definitive, as a stable balance between the input and output of some important chemical species, such as bicarbonate and nitrogen compounds has not yet been achieved. Moreover, recent investigations have revealed that insufficiently treated industrial and urban waste is once more being dumped in the lake. In this situation there can be no doubts as to the necessity for continuing research on Lake Orta, not only to document the evolution of the chemical and biological characteristics of the lake, but also to verify the effectiveness of the treatment measures adopted and to determine the need for extending these measures to the whole watershed. In particular, the object of this research should be to quantify, control and reduce to an acceptable level the incoming loads of a) ammoniacal nitrogen, to eliminate the danger of the lake water becoming re-acidified; b) phosphorus, to prevent the onset of eutrophication processes; c) heavy metals, to minimise their toxic effects on the whole aquatic ecosystem.
\end{abstract}

Key words: chemistry, heavy metals, nitrification, acidification, liming, lake recovery

\section{INTRODUCTION}

Over the last 70 years the water chemistry of Lake Orta has undergone a succession of major changes, which have affected the lake profoundly in different ways according to the triggering causes. The lake became seriously polluted after 1927 as a result of the discharge of copper and ammonium sulphate by a textile factory (Bemberg) which manufactures rayon by the cupro-ammoniacal method. Within a few years the lake had become an environment incompatible with the life of most of its pelagic and benthic organisms. From the $60 \mathrm{~s}$, metals discharged by a number of plating factories $(\mathrm{Cu}, \mathrm{Cr}, \mathrm{Ni}, \mathrm{Zn})$ added to the pollution, which was further aggravated by the acidification of the entire water mass, the result of processes of biochemical oxidation of ammonium to nitrate. Ammonium loads were drastically reduced in 1982, but in the lake the concentration of ammonium and the correlated strong acidity remained high due to the poor alkaline reserve in the watershed, as well as to the long theoretical renewal time of the water ( 8.5 years).

In 1987, on the basis of the scientific knowledge at its disposal and after formulating a predictive model of the pollution, the CNR Istituto Italiano di Idrobiologia of Pallanza proposed a direct recovery intervention to be effected by liming the lake (Bonacina et al. 1987; Calderoni et al. 1990a). The intervention, performed from May 1989 to June 1990, consisted in the addition to the lake of a suspension of $14800 \mathrm{t}$ of finely powdered limestone of natural origin. A total of $10,900 \mathrm{t}$ of pure calcium carbonate was sprayed on the lake's surface and pumped under the thermocline during the summer months.

The changes in the water chemistry of the lake from the $30 \mathrm{~s}$ to the beginning of the $90 \mathrm{~s}$ are summarised in the introductory chapter of this volume (Bonacina 2001a); they are documented by the results of a number of studies which have monitored the progressive deterioration of the lake's condition and the early stages of its recovery, and which have also researched the reasons 
for the continuous evolution in the chemical composition of the water (Monti 1930; Baldi 1949; Corbella et al. 1958; Picotti 1958; Tonolli \& Vollenweider 1961a; 1961b; Vollenweider 1963; Bonacina 1970; Bonacina \& Bonomi 1984; Bonacina et al. 1988a; 1988b; 1988c; Mosello et al. 1986a; 1986b; 1989; Calderoni et al. 1990b)

This paper presents the results of the liming and gives an up-to-date picture of the evolution of the main chemical characteristics of the lake. It also spells out the continuing risk of a return of the lake to polluted conditions, and suggests some possible protective measures.

\section{SAMPLING AND METHODS}

In the 13 years of research three stations were sampled with at least monthly frequency (Fig. 1):

- Qualba basin (Station A), at depths of 0, 10, 20,30, 50, 75, 100,120, $140 \mathrm{~m}$;

- Pettenasco basin (Station B), at depths of 0, 10, 20,30, 50, 75, 100,120 m;

- Buccione basin (Station C), at depths of 0, 10, 20, 30 $\mathrm{m}$.

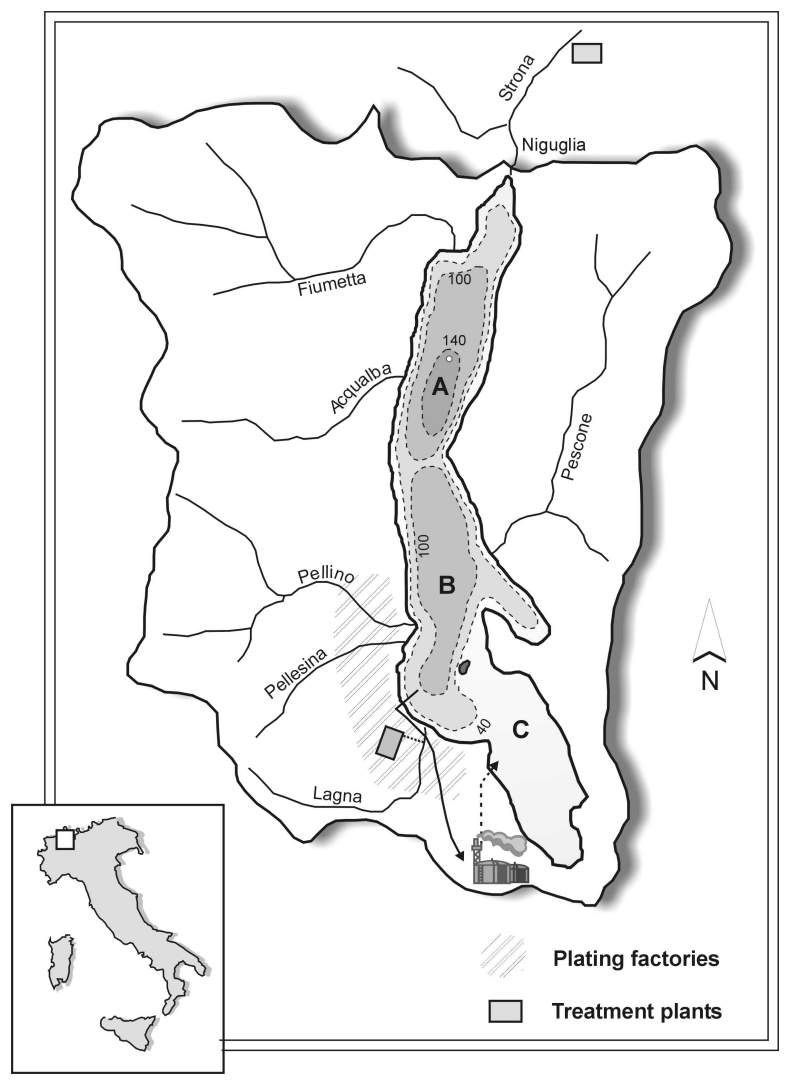

Fig. 1. Sampling stations in Lake Orta: Qualba (A); Pettenasco (B); Buccione (C).

Sampling was always performed in the Qualba ba$\mathrm{sin}$, in the zone of maximum depth of the lake $(-143 \mathrm{~m})$. Also sampled were the basins of Pettenasco (central zone of the lake, depth $120 \mathrm{~m}$ ) and Buccione (southern zone of the lake, depth $35 \mathrm{~m}$ ), every three weeks from 1989 to 1991 , and seasonally in 1992 and 1993. Altogether 152 samples were taken, as shown in table 1 .

Tab. 1. Number of annual samplings and sampling locations.

\begin{tabular}{cccc}
\hline & Qualba & $\begin{array}{c}\text { Qualba+ } \\
\text { Pettenasco+ } \\
\text { Buccione }\end{array}$ & $\begin{array}{c}\text { Total } \\
\text { annual } \\
\text { samplings }\end{array}$ \\
\hline 1988 & 12 & 0 & 12 \\
1989 & 3 & 14 & 17 \\
1990 & 1 & 15 & 16 \\
1991 & 0 & 13 & 13 \\
1992 & 7 & 5 & 12 \\
1993 & 7 & 4 & 11 \\
1994 & 11 & 1 & 12 \\
1995 & 10 & 2 & 12 \\
1996 & 9 & 0 & 9 \\
1997 & 11 & 0 & 11 \\
1998 & 11 & 0 & 11 \\
1999 & 13 & 0 & 13 \\
2000 & 3 & 0 & 3 \\
\hline
\end{tabular}

Samples were analysed for $\mathrm{pH}$, oxygen (Winkler method), conductivity, total alkalinity (acidimetric titration), main anions (sulphate, nitrate and chloride) by ion chromatography (Dionex); main cations (calcium, magnesium, sodium and potassium) by atomic adsorption spectrophotometry (AAS, Perkin Elmer 2380) and, from 1991, by ion chromatography (Dionex). Cu, Al, Fe, Mn, $\mathrm{Zn}, \mathrm{Cr}$ and $\mathrm{Ni}$ were measured by AAS (GAAS Perkin Elmer); ammonium, reactive silica and reactive phosphorus by spectrophotometry (indophenol-blue and ammonium molibdate with ascorbic acid, respectively). The methods employed were those most commonly used in limnological studies, and details of the quality controls used in the laboratory and of the sensitivity of the analyses are reported elsewhere (Tartari \& Mosello 1997).

\section{LAKE ORTA WATER CHEMISTRY FROM JANUARY 1988 TO MARCH 2000}

The liming profoundly changed the acid-base system of the whole water body, producing major variations in $\mathrm{pH}$ and the chemical variables directly involved in the processes of neutralisation and oxidation of the ammonium. It must be remembered that $\mathrm{pH}$ values remained acid continuously from 1962 to 1989 . The causes of this situation are to be sought in the biochemical oxidation of ammonium (Tonolli \& Vollenweider 1961a, 1961b; Vollenweider 1963; Gerletti \& Provini 1978; Mosello et al. 1986a; Bonacina et al. 1987; Schuurkes \& Mosello 1988; Mosello et al. 1991a); its overall reaction is as follows:

$$
\mathrm{NH}_{4}^{+}+2 \mathrm{O}_{2}=\mathrm{NO}_{3}^{-}+2 \mathrm{H}^{+}+\mathrm{H}_{2} \mathrm{O}
$$

The other mechanisms of production and/or consumption of hydrogen ions and ammonium, linked to 
reactions involving autochthonous or allochthonous organic substances as well as compounds of sulphur, iron and manganese, would appear to be negligible compared to the quantitative variations induced by the nitrification. In a well-buffered environment the acidity produced by the above reaction would be rapidly neutralised. This cannot happen in Lake Orta, as the poor original alkalinity reserve was quickly used up as early as the sixties and, besides, the bicarbonate loads from the watershed are far too inadequate to restore neutral conditions.

The first effect of the liming in 1990-1991 was an increase of $\mathrm{pH}$ to neutrality and a decrease in the mean acidity of the lake by $173 \mu \mathrm{eq} \mathrm{I}^{-1}$, a change which would have taken five years with the natural load of alkalinity from the watershed (Calderoni et al. 1991, 1993). The intervention also accelerated the rate of nitrification, which before the liming was enormously reduced, as the process could begin again only when $\mathrm{pH}$ had reached values of more than 4.7-4.8 (Calderoni \& Mosello 1990). After the liming the lake water chemistry continued to change, in so far as there was not yet a permanent balance between the loads of some important chemical variables entering the lake from the watershed and those leaving via the outflow. The evolution of these variables is described in the following sections.

\section{1. $p H$}

After the neutralisation of the lake water which immediately followed the liming, the trend of mean $\mathrm{pH}$ in the whole lake showed significant annual increases (Fig. 2).

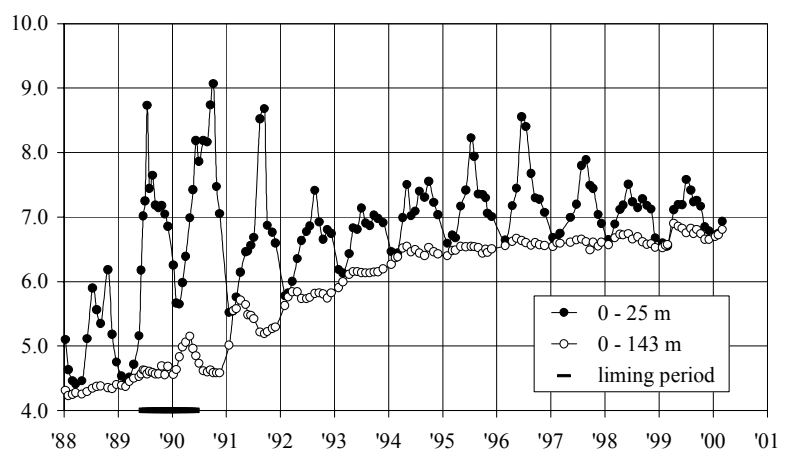

Fig. 2. $\mathrm{pH}$ in the epilimnetic layer $(0-25 \mathrm{~m})$ and in the whole lake $(0-143 \mathrm{~m})$ from January 1988 to March 2000 (volume weighted mean values).

Only in the late summer from 1990 to 1992 were there noticeable decreases linked to the processes of oxidation of ammoniacal nitrogen. From 1992 on, when the reserve of ammoniacal nitrogen still present in the lake was used up, $\mathrm{pH}$ continued to rise, no longer showing the typical autumn decline which had characterised the preceding years. At the spring circulation of
1993 it had reached a mean value of 6.1 on the whole column, gradually increasing to 6.9 in March 2000.

The mean values of $\mathrm{pH}$ in the epilimnion $(0-25 \mathrm{~m})$ reached maxima of around 9 during the liming, while in the following years the maxima gradually declined again to values of between 7 and 8.5, though seasonal increases in the epilimnion occurred. Note that, while the first peaks (1989-1991) are due to the combined effect of the calcium carbonate input and the processes of photosynthesis stimulated by the reduction in the toxicity of the water, the maximum values of the last few years have been determined exclusively by the intensity of the latter.

\subsection{Total alkalinity}

In-lake alkalinity was virtually absent before the liming: the loads of bicarbonate from the watershed were not sufficient to compensate for the hydrogen ion produced during the annual cycles of biochemical oxidation of ammoniacal nitrogen (Fig. 3). The liming intervention interrupted these processes of continual reacidification of the lake water by supplying a quantity of carbonate large enough to neutralise the low $\mathrm{pH}$ values and offset the theoretical acidity which would have been produced by the complete oxidation of the ammonium. This was possible because the neutralisation of the lake water prevented the rapid consumption of the bicarbonate loads arriving from the watershed, which had been the case since the early 60 s. It should be remembered that lakes acidified by atmospheric depositions are fed by tributaries which are already acid themselves, while the tributaries of Lake Orta have always had positive alkalinity values of between 0.2 and 0.3 meq $1^{-1}$ (Calderoni et al. 1990b, 1994).

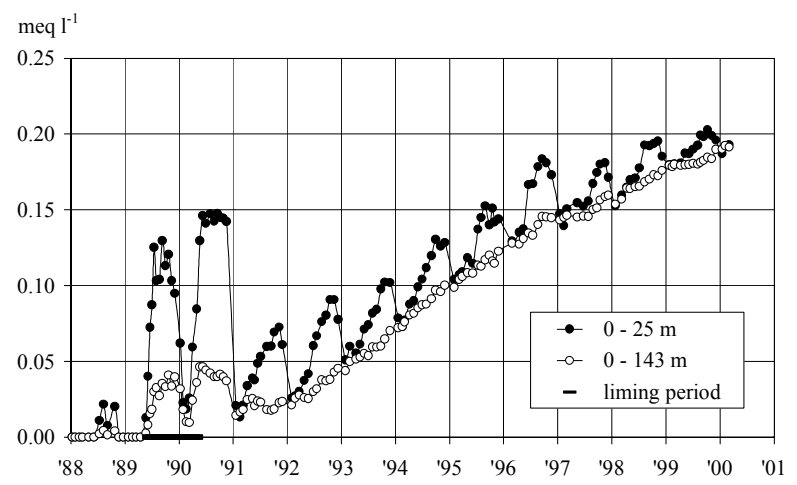

Fig. 3. Total alkalinity concentrations in the epilimnion $(0-25$ $\mathrm{m})$ and in the whole lake $(0-143 \mathrm{~m})$ from January 1988 to March 2000 (volume weighted mean values).

In particular, during the liming and up to 1992, there was wide seasonal fluctuation, with alkalinity decreasing in autumn and winter on account of the acidity produced by the oxidation of ammonium. These variations diminished progressively as the ammonium and the acidity produced by its oxidation became used up, stop- 
ping almost completely at the end of 1992, when the ammonium concentrations dropped to values lower than $0.05 \mathrm{mg} \mathrm{N}^{-1}$. In the years following the liming the loads from the tributaries gradually built up an alkaline reserve in the lake water, so that in March 2000 total alkalinity had reached 0.19 meq $^{-1}$, a value which eliminates the risk of any re-acidification.

The growth in alkalinity had already been predicted by the model devised to estimate the quantity of calcium carbonate which would be required for the liming (Calderoni et al. 1990a, Mosello et al. 1991b). The model had taken into consideration the acid-base loads arriving from the tributaries, from atmospheric precipitation and from urban and industrial sewage, as well as those leaving the lake via the outflow and the losses due to inlake transformations. So as to be able to measure contemporaneously the positive or negative alkalinity which would be present in the lake following the evolution of ammonium oxidation processes, we used a quantity defined as "potential alkalinity":

$$
\left[\mathrm{P}_{\mathrm{Alk}}\right]=[\mathrm{TA}]-\left[\mathrm{H}^{+}\right]-2\left[\mathrm{NH}_{4}^{+}\right]
$$

where $[\mathrm{TA}],\left[\mathrm{H}^{+}\right],\left[\mathrm{NH}_{4}^{+}\right]$are respectively the mean concentrations in the lake, expressed in $\mu \mathrm{eq} \mathrm{l}^{-1}$, of total alkalinity, hydrogen ion, and ammonium.

The value of the difference between $[\mathrm{TA}]$ and $\left[\mathrm{H}^{+}\right]$, if positive, corresponds to actual situations of alkalinity in the lake water mass ( $\mathrm{pH}$ values above 5.6); if close to zero, it indicates a $\mathrm{pH}$ in equilibrium with atmospheric $\mathrm{CO}_{2}$, equal to around 5.6; if negative, it indicates real conditions of acidity ( $\mathrm{pH}$ lower than 5.6). The term $2\left[\mathrm{NH}_{4}^{+}\right]$represents the potential acidity, i.e. the acidity which would be produced stoichiometrically by the complete oxidation of the ammonium to nitrate.

It can be seen in figure 4 how far the predictions of the model coincided with the experimental data measured in the lake, both before and during the liming (Calderoni et al. 1990a) and in the years following it (Calderoni unpublished). The figure shows in particular that the predicted equilibrium value, calculated on the basis of the current loads of $\mathrm{P}_{\mathrm{Alk}}$ from the watershed, i.e. 250 $\mu$ eq $1^{-1}$, has not yet been reached.

\subsection{Ammoniacal nitrogen}

The carbonate added during the liming intervention produced a rapid recovery of the biochemical oxidation of the ammonium to nitrate. The nitrification process was continuous and occurred in a very short time: from May 1989 to December 1990, the mean ammonium content in the lake dropped from 1.2 to $0.2 \mathrm{mg} \mathrm{N}^{-1}$ (Fig. 5). In the following years the decrease in concentrations was very rapid, and values close to zero were reached at the end of 1992, since when there have been no further decreases in $\mathrm{pH}$ or total alkalinity values.

However, in the two year period 1995-1996 there was a marked increase in the mean epilimnetic concentrations of ammonium, which reached levels slightly higher than $0.2 \mathrm{mg} \mathrm{N}^{-1}$. These values fell rapidly during the first stage of the winter circulation being diluted with the underlying water masses, but the consequent nitrification processes still caused the slight decrease in alkalinity already shown in figure 3 . These events, which have not recurred with the same intensity in subsequent years, can only be attributed to the renewed discharge of industrial waste. That this is the case is proved by the amount of the increases in the epilimnion, which are too large to be the result of an improbable sudden rise in loads of urban sewage, and by the fact that in the stratification period the levels of ammonium in the hypolimnion and in the deepest water remained unchanged and close to zero, indicating the absence of any release of ammonium from the sediment.

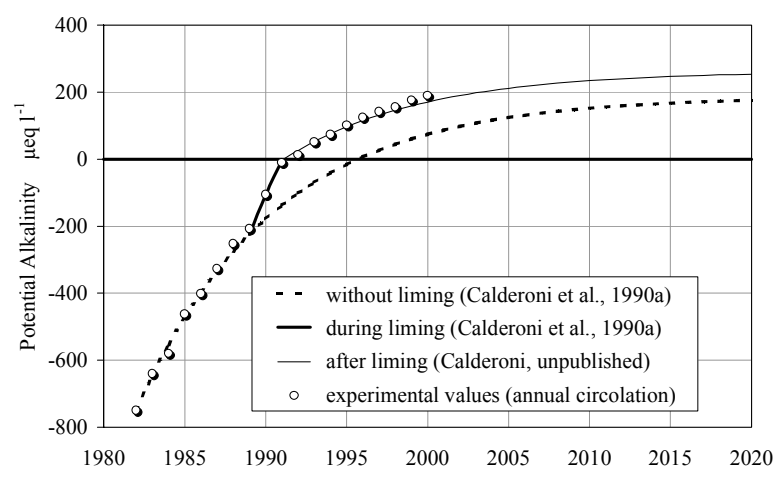

Fig. 4. Predicted in-lake trend of potential alkalinity, before, during and after liming, compared with the experimental values measured at the spring circulation (volume weighted mean values).

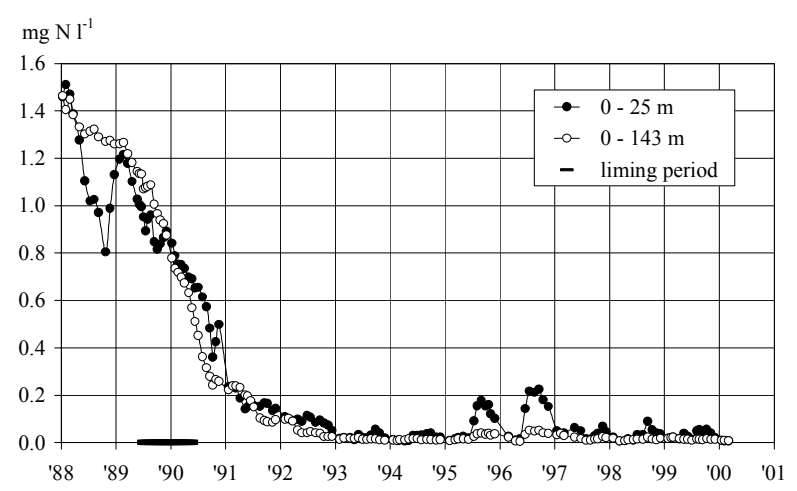

Fig. 5. Concentrations of ammoniacal nitrogen in the epilimnion $(0-25 \mathrm{~m})$ and in the whole lake $(0-143 \mathrm{~m})$ from January 1988 to March 2000 (volume weighted mean values).

\subsection{Nitric nitrogen}

The historical trend of nitric nitrogen concentrations in Lake Orta has been particularly affected by three phenomena: the oxidation of ammonium, the hydrological renewal of the lake waters, and its uptake by phytoplankton in the trophogenous zone. 
The first factor was the most prevalent from 1927 up to the beginning of the $60 \mathrm{~s}$, when the in-lake nitrogen content reached values of nearly $5.4 \mathrm{mg} \mathrm{N}^{-1}$. At that time the biochemical oxidation of the ammonium discharged by the Bemberg factory was particularly active because, due to the alkaline reserve in the lake, conditions were favourable for the growth of the nitrifying bacteria. During the next twenty years the acidification of the lake was instrumental in slowing down greatly the reactions of ammoniacal nitrogen oxidation. The mean nitrate levels remained relatively steady, or rather showed a slight decreasing trend, which became dramatically more marked after 1982, when the ammonium load from Bemberg was reduced from around 2500 to $30 \mathrm{t} \mathrm{a}^{-1}$. At that time the role of the water renewal was fundamental, as the nitrate concentrations in the tributaries (1.0-1.5 $\mathrm{mg} \mathrm{N}^{-1}$ ) were markedly lower than those in the lake, and the nitrates produced by oxidation had dropped sharply.

During the liming, which allowed a rapid recovery of the nitrifying processes, the nitric nitrogen concentration increased to values close to $4 \mathrm{mg} \mathrm{N}^{-1}$, measured in late autumn 1990 (Fig. 6). Since then its contents underwent a gradual decrease linked to the water renewal as well as to its uptake by phytoplankton. This decrease was briefly interrupted in the second half of 1997, when there was a slight rise in the mean concentrations of the whole water mass from 2.2 to $2.3 \mathrm{mg} \mathrm{N} \mathrm{l}^{-1}$, whereas the minimum in the epilimnion was far less marked than that previously measured. This fact should probably be seen in relation to the higher loads of ammoniacal nitrogen from the watershed of the previous two years. The mean nitrate contents began to decrease again in 1998; at the 2000 circulation, their values were the lowest recorded in the whole study period $\left(2.0 \mathrm{mg} \mathrm{N}^{-1}\right)$.

\subsection{Oxygen}

The oxygen saturation trend shows seasonal maxima in the epilimnion which are always between 120 and $130 \%$ saturation, with a sole exception in 1988 when lower percentages of 100-110\% were recorded (Fig. 7). These values are indicative of a rather high production of algae, typical of mesotrophic lakes. In the case of Lake Orta, however, the lack of a pelagic fish population (Giussani 1990), and the peculiarity of a zooplankton population which is still small and poorly structured, are factors which, acting together, result in a less efficient control of algae (Ruggiu \& Morabito 1990; Pizzolon et al. 1992; Morabito \& Curradi 1997; Bonacina \& Pasteris 2001; Morabito et al. 2001). The consumption of oxygen in the hypolimnion depends essentially on the mineralisation of the organic substance and on the oxidation of ammonium. Consumption was particularly high during the periods of greater nitrification, between 1989 and 1992, when the mean saturation in the hypolimnion reached minima of around $25 \%$, and in the two-year period 1997-1998, with a minimum of around $50 \%$. In the years following the complete elimination of the ammonium, oxygen consumption was much smaller, with saturation minima between 70 and $75 \%$.

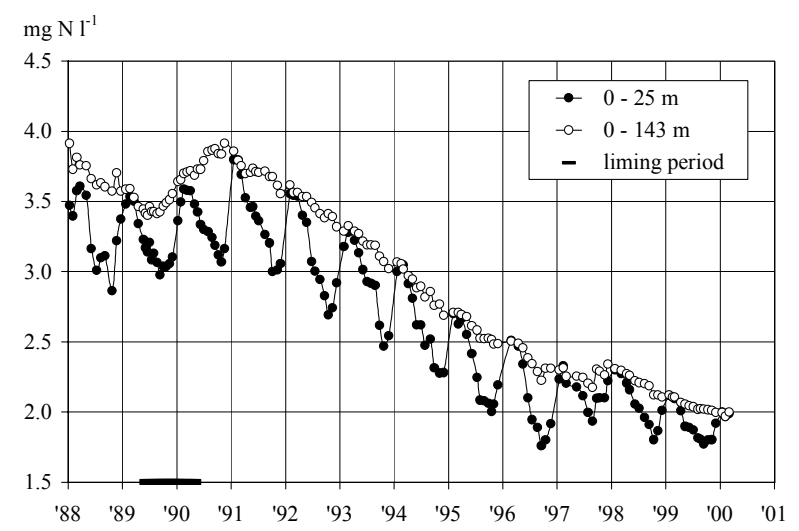

Fig. 6. Nitric nitrogen concentrations in the epilimnion $(0-25$ $\mathrm{m})$ and in the whole lake $(0-143 \mathrm{~m})$ from January 1988 to March 2000 (volume weighted mean values).

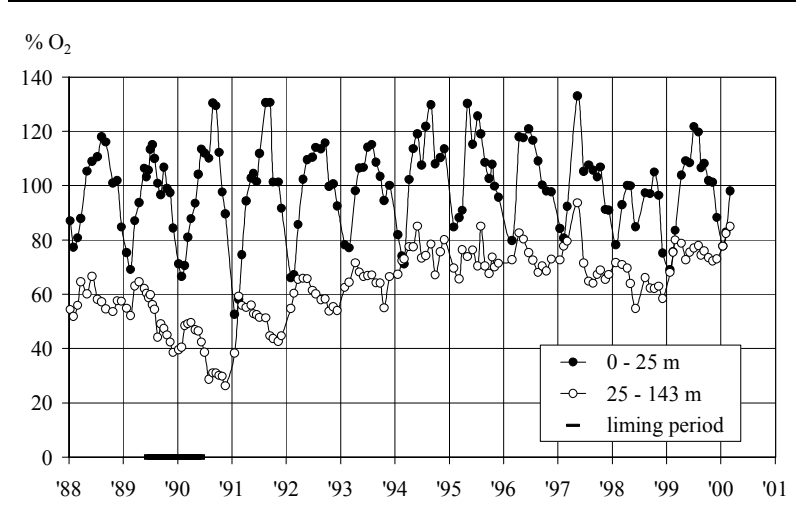

Fig. 7. Percentage of oxygen saturation in the epilimnion (0$25 \mathrm{~m})$ and the hypolimnion $(25-143 \mathrm{~m})$ from January 1988 to March 2000 (volume weighted mean values).

\subsection{Reactive silicate}

Before the liming, the concentrations of reactive silica in the lake water had maintained steady values of around $4.5 \mathrm{mg} \mathrm{Si}^{-1}$, a content very similar to that found on average in the tributaries, but distinctly higher than the values measured in the nearby Lake Mergozzo (1.5$\left.1.7 \mathrm{mg} \mathrm{Si}^{-1}\right)$, the watershed of which has geo-chemical characteristics identical to those of Lake Orta (Calderoni \& Marchetto 1998). This difference is probably linked to the scarcity of diatoms, which had become rare among the Lake Orta phytoplankton until their complete disappearance when the acidity became established and toxic metals persisted at high concentrations (van Dam \& Mertens 1990; Calderoni et al. 1992a; 1992b; Ruggiu et al. 1998). For decades, therefore, the major mechanism in the reduction of silicate was absent: that is, its assimilation for the formation of diatom valves, and the subsequent segregation in the sediment of frustules made up of very poorly soluble siliceous material. 
Then, during the liming, diatom blooms reappeared, and in very few years had determined a marked drop in the mean in-lake concentration of silicate, which have now levelled out around $2.9 \mathrm{mg} \mathrm{Si} \mathrm{l}^{-1}$ (Fig. 8). The decreases in the epilimnion are even more striking: during the liming, and in the summers after 1995, concentrations dropped to levels of 2.5 and around $2.0 \mathrm{mg} \mathrm{Si}^{-1}$ respectively.

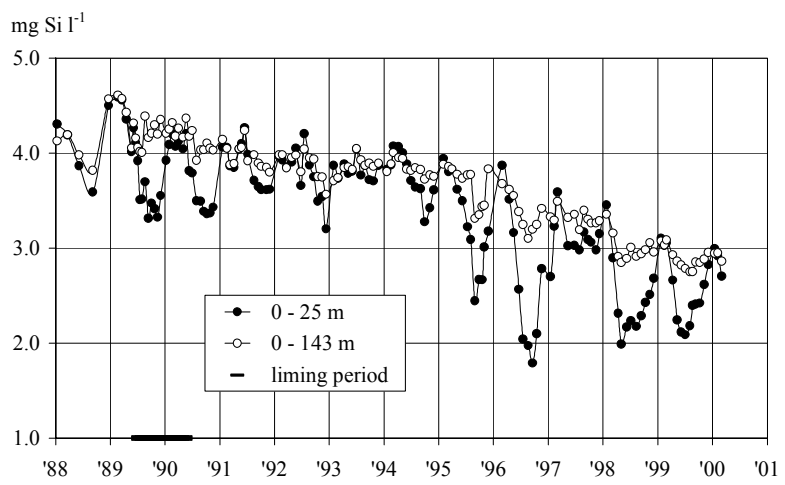

Fig. 8. Reactive silicate concentrations in the epilimnion $(0-25$ $\mathrm{m})$ and in the whole lake $(0-143 \mathrm{~m})$ from January 1988 to March 2000 (volume weighted mean values).

\subsection{Heavy metals}

In general, the metals analysed show clearly the strong relationship between their concentrations and $\mathrm{pH}$ values; this relationship has already been studied in detail (Mosello et al. 1986b, 1989; Mosello \& Calderoni 1990; Camusso et al. 1992). Copper and aluminium, both of which are elements of major importance in determining the change in the lake water quality, may be taken as good examples of the situation (Fig. 9). The two metals have different origins. The copper comes from industrial discharge, and its loads were reduced substantially after 1982 . The origin of the aluminium is essentially suspended matter carried by the tributaries; in fact, inorganic particulate contains typical constituents of soil, such as aluminium-silicates, which in an acid environment are partly dissolved, giving rise to solutions with a high aluminium content. The copper in the lake water reached its highest concentrations, over $100 \mu \mathrm{g} \mathrm{l}^{-1}$, in the mid-fifties (Picotti 1958; Vollenweider 1963), decreasing thereafter to $35 \mu \mathrm{g} \mathrm{l}^{-1}$ in the period before the liming.

The liming caused an initial reduction in the concentrations to around $25 \mu \mathrm{g} \mathrm{l}^{-1}$; after this, the values decreased steadily as the mean $\mathrm{pH}$ in the lake increased, until at the spring circulation of 1999 the concentrations in the whole water mass were around $4 \mu \mathrm{g} \mathrm{Cu} \mathrm{l}^{-1}$ (Fig. 10). The same figure shows very marked seasonal fluctuations in the epilimnion, linked to the variations in $\mathrm{pH}$ determined by the activity of algal synthesis: for several months in the summer and autumn, copper concentrations remained below $7 \mu \mathrm{g} \mathrm{l}^{-1}$, even when the mean content in the whole lake was still between 15 and 30 $\mu \mathrm{g} \mathrm{l}^{-1}$. This drastic seasonal reduction in the epilimnion allowed the development of biological activity without the risk of the episodes of acute toxicity which had been a feature of previous years.

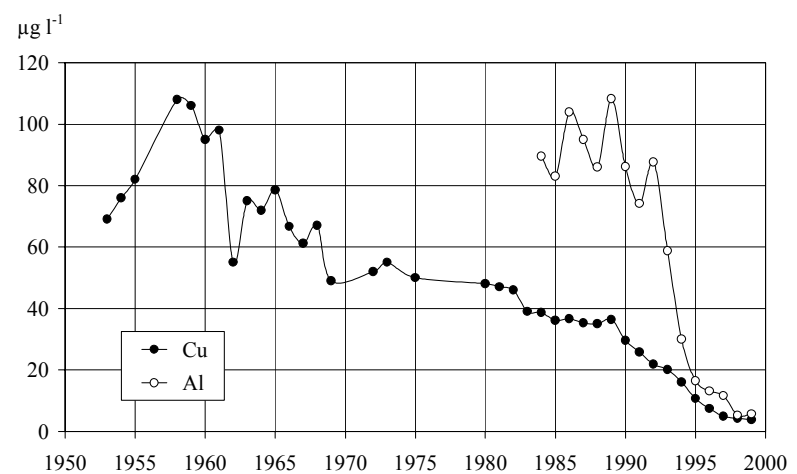

Fig. 9. Trend of mean concentrations of copper and aluminium in the whole lake from 1953 to 1999 (volume weighted values at spring circulation).

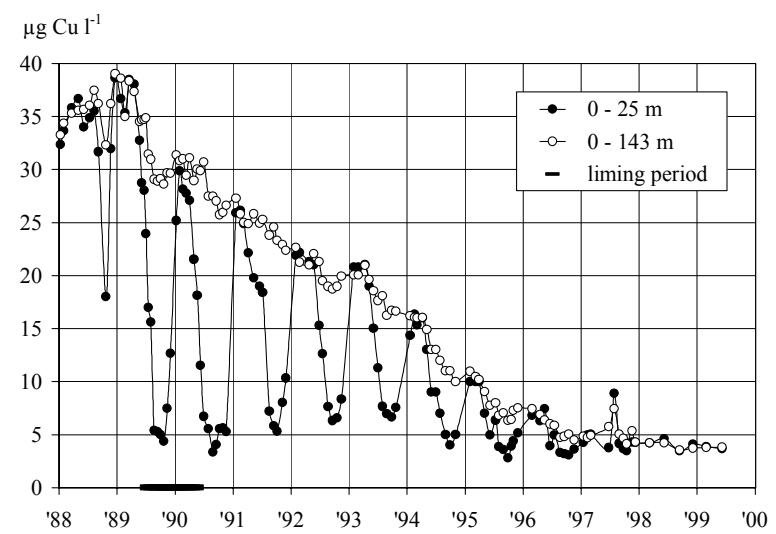

Fig. 10. Copper concentrations in the epilimnion (0-25 m) and in the whole lake from 1953 to 1999 (volume weighted mean values at spring circulation).

The highest concentrations of aluminium (110-115 $\mu \mathrm{g} \mathrm{l}^{-1}$ ) were reached in the second half of the $80 \mathrm{~s}$ (Fig. 9), when $\mathrm{pH}$ in the whole water mass was between 3.9 and 4.3 units. During the liming, the mean aluminium content dropped sharply, to around $70 \mu \mathrm{g} \mathrm{l}^{-1}$, but during 1991 it rose again to levels of $90 \mu \mathrm{g}^{-1}$ (Fig. 11). In the same period, however, the concentrations in the epilimnion presented seasonal minima well below $30 \mu \mathrm{g} \mathrm{l}^{-1}$. The steepest drop in the whole lake began only in 1992, when the ammonium still present was almost completely oxidised, and the mean $\mathrm{pH}$ was close to the threshold of 6 units. From the autumn of that year the mean aluminium content decreased steadily to the minimum of $6 \mu \mathrm{g}^{-1}$ measured at the 1999 circulation.

Similar reductions, linked to the variations in $\mathrm{pH}$, were also found for the other metals ( $\mathrm{Zn}, \mathrm{Fe}$ and $\mathrm{Mn}$ in Fig. 12; $\mathrm{Cr}$ and $\mathrm{Ni}$ in Fig. 13). Iron, which was present at mean levels over $80 \mu \mathrm{g} \mathrm{l}^{-1}$ during the years of the 
strongest acidification, had already dropped dramatically to values below $10 \mu \mathrm{g}^{-1}$ during the first stage of the liming, when $\mathrm{pH}$ had risen above 5 .

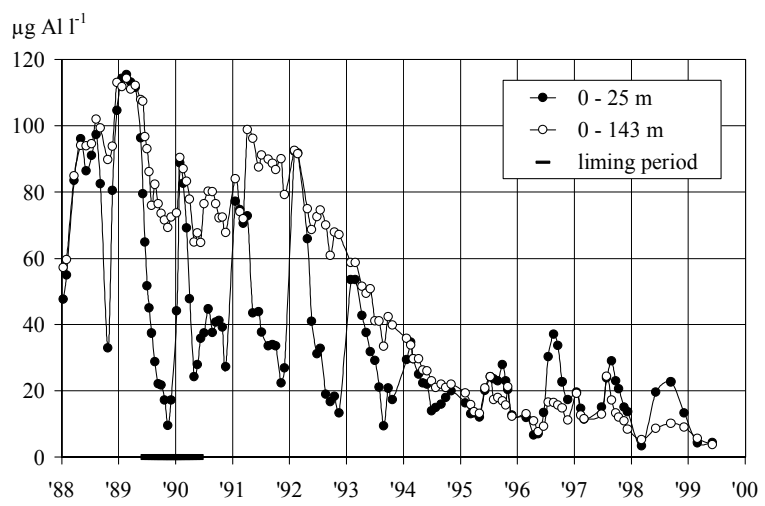

Fig. 11. Aluminium concentrations in the epilimnion and in the whole lake from 1953 to 1999 (volume weighted mean values at spring circulation).

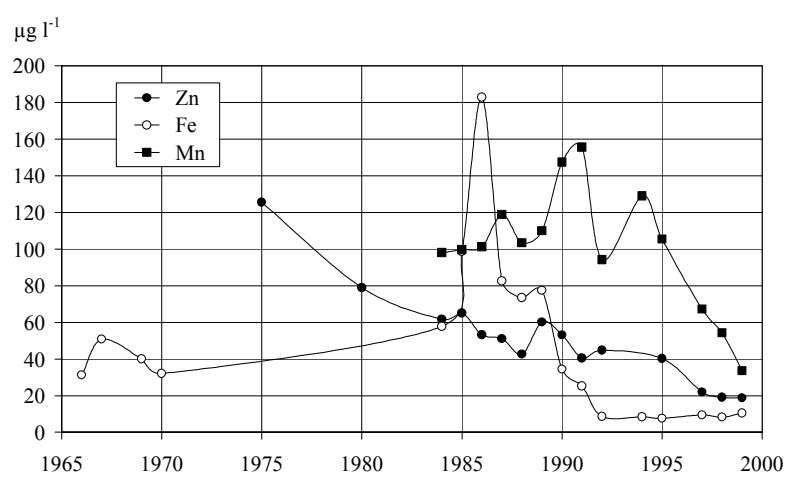

Fig. 12. Trend of mean concentrations of zinc, iron and manganese in the whole lake from 1965 to 1999 (volume weighted mean values at spring circulation).

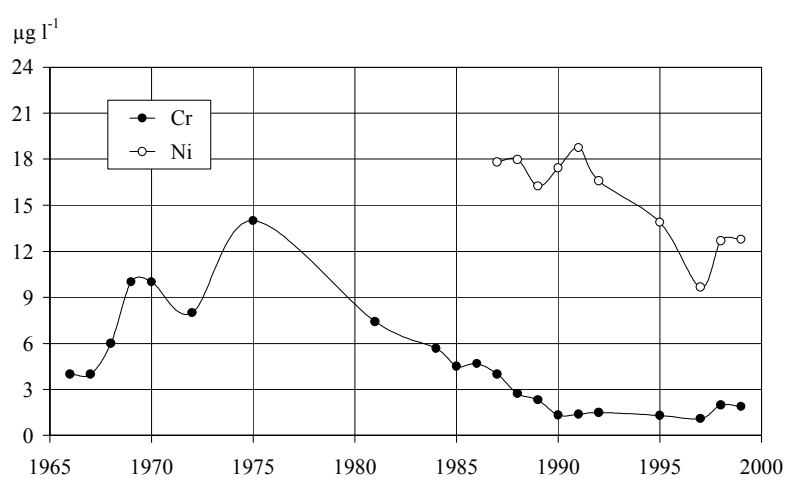

Fig. 13. Trend of mean concentrations of nickel and chromium in the whole lake from 1965 to 1999 (volume weighted mean values at spring circulation).

The trends of the mean concentrations of zinc, nickel and manganese were similar to those of aluminium, in the sense that their greatest reduction was seen only after 1992 for $\mathrm{pH}$ values which were by this time over 6 . The effect of the increase in $\mathrm{pH}$ on the mean content of chromium is less noticeable, because its in-lake concentrations had already dropped sharply before the liming due to better treatment of industrial discharge.

\section{DISCUSSION AND CONCLUSIONS}

Implementing the liming project brought forward by 5 years the recovery of the alkaline reserve in Lake Orta. The most important results, apart from the neutralisation of the whole water mass, were the immediate resumption of nitrification, which before the liming had slowed down greatly and was almost completely inhibited by the acidity in the lake; the reconstruction of an adequate alkalinity reserve; and the considerable decrease of the toxic metals dissolved in the water. The full recovery of the quality of the water meant that bathing was again possible from all the beaches of the lake after decades of prohibition (Ballarè et al. 1992). Furthermore, the solution of the historical problems within the lake, regarding the acidity and the massive presence of ammonium and toxic metals, has led to a positive response by the various biological communities.

From a historical angle, an analysis of the mean $\mathrm{pH}$ values of the whole water mass at the circulation from 1926 to 2000 shows that the current $\mathrm{pH}$ values are by now close to the original ones (Fig. 14). The effectiveness of the liming thus remedied a situation of high acidity which for nearly thirty years, from 1962 to 1989 , had characterised the chemistry of the lake water.

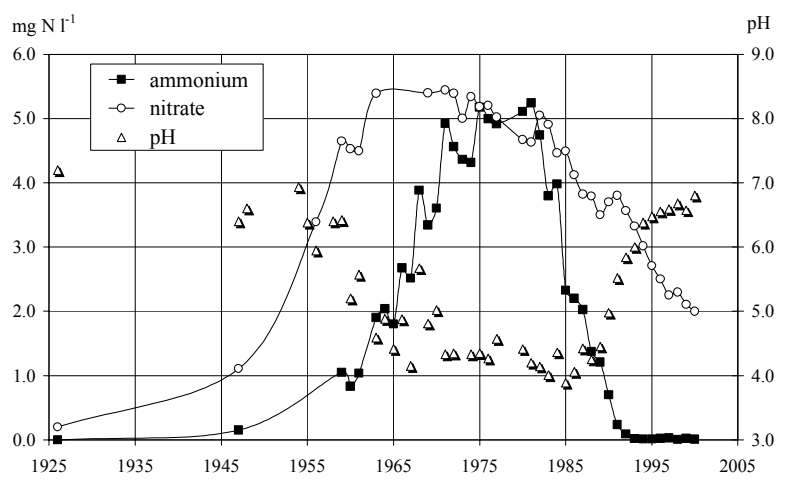

Fig. 14. Evolution of $\mathrm{pH}$, ammoniacal and nitric nitrogen in the whole lake from 1925 to 1998 (volume weighted mean values at spring circulation).

The historical evolution of nitrate and ammonium concentrations shows that the highest contents $(5.4 \mathrm{mg}$ $\mathrm{N}-\mathrm{NO}_{3} \mathrm{I}^{-1}$ and $5.2 \mathrm{mg} \mathrm{N}-\mathrm{NH}_{4} \mathrm{l}^{-1}$ ) were measured respectively between 1963 and 1974 and at the beginning of the 80s (Fig. 14). After that, around ten years and the liming intervention were required to eliminate the ammonium from the lake.

But because of the nitrification, the in-lake concentrations of nitrate are still far from the steady state, i.e. a 
condition of equilibrium resulting from the balance between the input and output of the various compounds of nitrogen and from the in-lake processes. We may hypothesise that the equilibrium concentrations could be slightly lower than those of the tributaries, just because there is in the lake in any case an uptake of nitrogen for biological processes.

At the moment, then, the condition of Lake Orta is more than acceptable. But the situation must be monitored continuously to prevent the polluting loads from exceeding those measured during the liming period. The limits set by current legislation must be strictly applied, as there have been signs recently that insufficiently treated industrial effluent is once again reaching the lake. This may be seen quite clearly from the trend of ammoniacal nitrogen concentrations in the epilimnion (Fig. 5), which in the two year period 1995-1996 increased to such an extent that they could not possibly have originated in urban sewage. Up to now the lake has fortunately proved able to absorb these sometimes lengthy episodes of renewed pollution without undue stress, thanks to the re-constitution of its alkaline reserve and to the present normal $\mathrm{pH}$ values. But if this problem is not resolved, or worse, if the ammonium loads were to increase further, there is a clear risk that the lake will again become acidified, with all the dramatic consequences which are now common knowledge.

The concentrations of toxic metals found at the 1999 circulation are also very far from those found in natural conditions, and indicate that their input is still too high. The causes are largely to be found in the effluents from a number of plating factories in the south-western part of the watershed, and from the Lake Orta Consortium treatment plant. This plant was set up in the early 80 s to treat urban sewage, but has always worked under great difficulty because the bacterial flora in the biological section was poisoned by toxic metals originating in the industrial effluent of the area, the volume of which is as large as the volume from non-industrial sources (Lacqua et al. 1983). In these conditions, not even the recent improvements in the plant, with the adoption of chemical-physical systems for metal treatments and for sand-filtering terminal effluent, appear to have had altogether acceptable results. In fact, while there is an undoubted improvement in the mean quality of the discharge, the outgoing concentrations of copper and other metals occasionally exceed the limits set out in Table A of Law 319/76, whenever there are inputs to the sewers of the Consortium of sudden discharges containing excessive and illegal levels of pollutants which condition the effectiveness of the treatments (Lacqua, pers. comm.).

The water chemistry of the lake has not yet reached a steady-state. The most significant variations in the mean solute content and in the ionic balance of the last 20 years are given in table 2 , which shows a substantial stability of concentrations only for sulphate and potassium, as well as for magnesium and chloride, which show a very slightly increasing trend. All the other ionic species present increasing or decreasing trends, both as a result of the liming having changed the pre-existing acid-base system, and as an effect of major variations in loads of discharges from the watershed. In particular, the use from 1982 of $\mathrm{Ca}(\mathrm{OH})_{2}$ instead of sodium hydroxide to neutralise the Bemberg effluent, and the abundant consumption of $\mathrm{Ca}(\mathrm{OH})_{2}$ in the early phase of clarification and flocculation in the Consortium treatment plant, which was activated in the first half of the $90 \mathrm{~s}$, further increased the concentration of calcium in the lake. Its growth was greatest during the liming, and continued until it reached its present maxima of $14 \mathrm{mg}$ $\mathrm{Ca}^{-1}$. At the same time, sodium concentrations decreased to $4.2-4.4 \mathrm{mg} \mathrm{Na}^{-1}$ (Fig. 15).

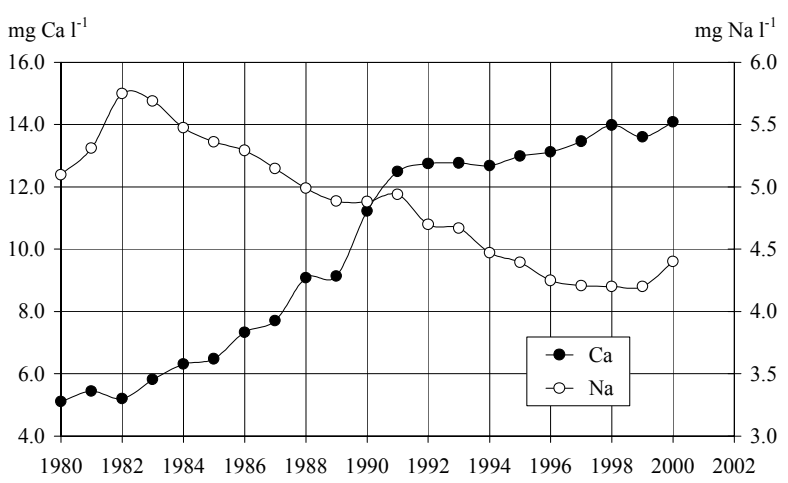

Fig. 15. Evolution of calcium and sodium concentrations in the whole lake from 1980 to 2000 (volume weighted mean values at spring circulation).

A further reason for concern involves the future evolution of the trophic level of the lake, despite the low mean values of reactive and total phosphorus concentration measured in the last 20 years: respectively 1-3 $\mu \mathrm{g} \mathrm{P} \mathrm{l}^{-1}$ and $5 \mu \mathrm{g} \mathrm{P}{ }^{-1}$. Studies on the tributaries reveal that the annual phosphorus loads from the watershed, from urban and industrial sources, exceed the permitted loadings (Richetti 1995). This may cause a trophic increase in the ecosystem in a relatively short time, as the rapid and continual re-constitution of the lake's alkaline reserve has almost completely halted the chemicalphysical mechanisms of phosphorus removal by sedimentation. These mechanisms were especially active not only during the liming intervention but also in the succeeding years, as a result of processes of precipitation and/or co-precipitation of basic salts of iron and aluminium, which depend on $\mathrm{pH}$.

To conclude: the liming intervention solved the historical problems within the lake associated with the acidity and the massive presence of ammonium and toxic metals, to the extent that Lake Orta, after being known for decades as a classic case of industrial pollution, is today recognised as an example of environ- 
Tab. 2. Chemical characteristics and ionic balance in Lake Orta at the circulation (FebruaryMarch of every year). Volume weighted mean values measured before and after the activation of the Bemberg treatment plant (1982) and the liming intervention (May 1989-June 1990).

\begin{tabular}{|c|c|c|c|c|c|c|}
\hline & & 1981 & 1985 & 1989 & 1992 & 2000 \\
\hline Conductivity $\left(20^{\circ} \mathrm{C}\right)$ & $\mu \mathrm{S} \mathrm{cm} \mathrm{cm}^{-1}$ & 136 & 153 & 115 & 106 & 112 \\
\hline $\mathrm{pH}$ & & 4.20 & 3.90 & 4.37 & 5.84 & 6.80 \\
\hline Total Alkalinity $\left(\mathrm{HCO}_{3}^{-}\right)$ & $\mu$ eq $1^{-1}$ & 0 & 0 & 0 & 28 & 191 \\
\hline $\mathrm{SO}_{4}^{--}$ & $\mu$ eq $1^{-1}$ & 657 & 653 & 639 & 664 & 635 \\
\hline $\mathrm{NO}_{3}^{-}$ & $\mu$ eq $1^{-1}$ & 343 & 321 & 256 & 254 & 143 \\
\hline $\mathrm{Cl}^{-}$ & $\mu$ eq $1^{-1}$ & 74 & 66 & 68 & 68 & 79 \\
\hline $\mathrm{Ca}^{++}$ & $\mu$ eq $1^{-1}$ & 264 & 329 & 453 & 636 & 703 \\
\hline $\mathrm{Mg}^{++}$ & $\mu$ eq $1^{-1}$ & 123 & 123 & 129 & 137 & 132 \\
\hline $\mathrm{Na}^{+}$ & $\mu$ eq $1^{-1}$ & 248 & 239 & 217 & 204 & 191 \\
\hline $\mathrm{K}^{+}$ & $\mu$ eq $1^{-1}$ & 29 & 28 & 27 & 25 & 25 \\
\hline $\mathrm{H}^{+}$ & $\mu$ eq $1^{-1}$ & 63 & 126 & 43 & 1 & 0 \\
\hline $\mathrm{NH}_{4}^{+}$ & $\mu$ eq $1^{-1}$ & 332 & 164 & 90 & 6 & 1 \\
\hline$\sum$ anions & $\mu$ eq $1^{-1}$ & 1074 & 1040 & 963 & 1014 & 1048 \\
\hline$\sum$ cations & $\mu$ eq $1^{-1}$ & 1059 & 1009 & 959 & 1009 & 1052 \\
\hline
\end{tabular}

mental recovery. There is however a danger that the effectiveness of the recovery so far achieved may be seriously endangered if the industrial and urban discharges reaching the lake are not more strictly controlled.

In the light of this situation, continuing research is more essential than ever, not only to document the evolution of the chemical and biological characteristics of the lake, but also to make sure that the treatments adopted are being applied correctly, and to encourage their extension, if necessary, to the whole watershed. In particular, research should be aimed at quantifying, controlling and reducing to acceptable levels the incoming loads of ammoniacal nitrogen, to obviate the risks of the re-acidification of the water; of phosphorus, to prevent the onset of eutrophication processes; of heavy metals, to minimise their toxic impact on the whole lake ecosystem, with particular attention being paid to the disposal of toxic and harmful waste generated by manufacturing activity, including the metal highly concentrated solutions from the plating factories.

\section{REFERENCES}

Baldi, E. 1949. Il Lago d'Orta, suo declino biologico e condizioni attuali. Mem. Ist. ital. Idrobiol., 5: 145-188.

Ballaré, G., E. Bielli, G. Fornara \& P. Masseroni. 1992. Qualità e utilizzo delle acque litorali del Lago d'Orta. In: Calderoni, A. \& R. de Bernardi (Eds). Atti Conv.: "Orta, un lago da salvare: le fasi del suo recupero", Orta, 9-10 Aprile 1990. Documenta Ist. ital. Idrobiol., 38: 83-94.

Bonacina, C. 1970. Il Lago d'Orta: ulteriore evoluzione della situazione chimica e della struttura della biocenosi planctonica. Mem. Ist. ital. Idrobiol., 26: 141-204.

Bonacina, C. 2001. Lake Orta: the undermining of an ecosystem. J. Limnol., 60(1): 53-59.

Bonacina, C. \& G. Bonomi. 1984. I grandiosi effetti ambientali determinati dalle prime fasi del disinquinamento del Lago d'Orta. Documenta Ist. ital. Idrobiol., 2: 24 pp.

Bonacina, C. \& A. Pasteris. 2001. Zooplankton of Lake Orta after liming: an eleven years study. J. Limnol., 60(1): 101109.
Bonacina, C., G. Bonomi, A. Calderoni \& R. Mosello. 1987. Evoluzione recente dell'inquinamento del Lago d'Orta e proposta di un intervento per il suo recupero. Atti Simposio: "Deposizioni acide: un problema per acque e foreste". Documenta Ist. ital. Idrobiol., 14: 197-213.

Bonacina, C., G. Bonomi, L. Barbanti, R. Mosello, D. Ruggiu \& G. Tartari. 1988a. Lake Orta (N. Italy): recovery after the adoption of restoration plans. In: N.W. Schmidtke (Ed.), Toxic contamination in Large Lakes. Volume II. Impact of Toxic Contaminants on Fisheries Management. Lewis Publishers: 101-130.

Bonacina, C., G. Bonomi, L. Barbanti, R. Mosello \& D. Ruggiu. 1988b. Recovery of an industrially acidified, ammonia and heavy metal polluted lake (Lake Orta, N. Italy), due to the adoption of treatment plants. Verh. int. Ver. Limnol., 23: 535-544.

Bonacina, C., A. Calderoni \& R. Mosello. 1988c. Il Lago d'Orta: evoluzione dell'inquinamento ed interventi diretti al recupero di uno dei più grandi laghi acidi del mondo. Acqua Aria, 20: 69-74.

Calderoni, A. \& R. Mosello. 1990. Evoluzione delle caratteristiche chimiche del Lago d'Orta nel quadriennio Febbraio 1984-Febbraio 1988. In: Bonacina, C., A. Calderoni \& R. de Bernardi (Eds), Ricerche limnologiche sul Lago d'Orta finalizzate al suo risanamento. Documenta Ist. ital. Idrobiol., 28: 71-88.

Calderoni, A., R. de Bernardi \& R. Mosello. 1990a. Proposta di risanamento del Lago d'Orta tramite liming. In: Bonacina, C., A. Calderoni \& R. de Bernardi (Eds), Ricerche limnologiche sul Lago d'Orta finalizzate al suo risanamento. Documenta Ist. ital. Idrobiol., 28: 117-131.

Calderoni, A., R. de Bernardi \& R. Mosello. 1990b. L'inquinamento del Lago d'Orta ed il suo risanamento mediante liming. Inquinamento, 11: 1-11.

Calderoni, A., R. Mosello \& A. Quirci. 1991. Chemical response of Lake Orta (Northern Italy) to liming. Arch. Hydrobiol., 122: 421-439.

Calderoni, A., R. de Bernardi \& D. Ruggiu. 1992a. Variazioni ecosistemiche nel Lago d'Orta a seguito degli interventi di liming. In: Marchetti, R. \& R. Cotta Ramusino (Ed.), Atti Congresso S.It.E. 15, Milano, 21-25 Settembre 1992: 363383.

Calderoni, A., R. Mosello \& D. Ruggiu. 1992b. Sixty years of limnology on Lago d'Orta: a case history of recovery from heavy pollution. In: Guilizzoni P., G. Tartari \& G. Gius- 
sani (Eds), Limnology in Italy. Mem. Ist. ital. Idrobiol., 50: 201-223.

Calderoni, A., R. de Bernardi \& R. Mosello. 1993. Lago d'Orta ecosystem recovery by liming. In: S.E. Jørgensen (Ed.), Guideline Lake Management, 5. ILEC, UNEP: 105144 .

Calderoni, A., R. de Bernardi \& R. Mosello. 1994. Recovery of Lago d'Orta by liming. Verh. int. Ver. Limnol., 25 : 2016-2020.

Calderoni, A. \& A. Marchetto. 1998. La situazione ambientale del Lago di Mergozzo. In: Calderoni, A. \& A. Marchetto (Eds), Stato delle conoscenze sulla situazione ambientale dei laghi piemontesi. Report CNR-III-04.98: 74-81.

Camusso, M., G. Tartari, M. Renoldi, P. Riva, R. Mosello, A. Calderoni, G.A. Tartari, A. Quirci, H. Muntau, G. Marengo, R. Cenci, B. Klüssendorf, A. Lattanzio, M Bianchi \& R. Vivian. 1992. Effetti dell'intervento di liming sulle concentrazioni dei metalli nelle acque lacustri. In: A. Calderoni \& R. de Bernardi (Eds), Atti Conv: "Orta, un lago da salvare: le fasi del suo recupero", Orta, 9-10 Aprile 1990. Documenta Ist. Ital. Idrobiol., 38: 5370.

Corbella, C., V. Tonolli \& L. Tonolli. 1958. I sedimenti del Lago d'Orta, testimoni di una disastrosa polluzione cuproammoniacale. Mem. Ist. ital. Idrobiol., 10: 9-52.

Gerletti, M. \& A. Provini. 1978. Effect of nitrification in Orta Lake. Prog. Wat. Tech., 10: 839-851.

Giussani, G. 1990. La fauna ittica del Lago d'Orta. In: Bonacina, C., A. Calderoni \& R. de Bernardi (Eds), Ricerche limnologiche sul Lago d'Orta finalizzate al suo risanamento. Documenta Ist. ital. Idrobiol., 28: 109-115.

Lacqua, P., V. Bignami \& G. Galbusera. 1983. Indagine chimica sulle acque reflue provenienti dalla rete fognaria dei comuni di San Maurizio d'Opaglio e Pella in entrata all'impianto di depurazione consortile di Lagna. Consorzio Depurazione Acque Reflue del Cusio. Technical report: $10 \mathrm{pp}$.

Monti, R. 1930. La graduale estinzione della vita del Lago d'Orta. Rend. R. Ist. lomb. Sci. Lett., 63: 3-22.

Morabito, G. \& M. Curradi. 1997. Phytoplankton community structure of a deep subalpine Italian lake (Lake Orta, N. Italy) four years after the recovery from acidification by liming. Int. Revue ges Hydrobiol., 82: 487-506.

Morabito, G., D. Ruggiu \& P. Panzani. Trends of phytoplankton characteristics and their communities in pre- and post-liming time in Lake Orta (1984-1998). J. Limnol., 60(1): 91-100.

Mosello, R., C. Bonacina, A. Carollo, V. Libera \& G.A. Tartari. 1986a. Acidification due to in-lake ammonia oxidation: an attempt to quantify the proton production in a highly polluted subalpine italian lake (Lake Orta). Mem. Ist. ital. Idrobiol., 44: 47-71.

Mosello, R., R. Baudo \& G.A. Tartari. 1986b. Metal concentrations in a highly acidic lake: L. Orta (Northern Italy). Mem. Ist. ital. Idrobiol. 44: 73-96.
Mosello, R., A. Calderoni \& G.A. Tartari. 1989. pH related variations of trace metal concentrations in L. Orta. Sci. Total Environ., 87/88: 255-268.

Mosello, R. \& A. Calderoni. 1990. Pollution and recovery of Lake Orta (Northern Italy). In: Giesy, J. P., R. Baudo \& H. Muntan (Eds), Sediment chemistry and toxicity of in-place pollutants. Lewis Publishers, Ann Arbor: 349-363.

Mosello, R., A. Calderoni \& A. Quirci. 1991a. Il recupero del Lago d'Orta. Le Scienze, 280: 38-47.

Mosello, R., A. Calderoni \& R. de Bernardi. 1991b. Mass budget as a tool for predicting the response to liming of the acidified, ammonium polluted L. Orta. Verh. int. Ver. Limnol., 24: 1044-1048.

Picotti, M. 1958. Ricerche nel Lago d'Orta. Boll. Pesca Piscic. Idrobiol., 12: 126-158.

Pizzolon, L., D. Ruggiu \& G. Morabito. 1992. Primary production and phytoplankton communities in the acidified Lake Orta (N. Italy) after the removal of ammonia pollution. Mem. Ist. ital. Idrobiol., 51: 29-52.

Richetti, S. 1995. Le modificazioni dell'idrochimica del Lago d'Orta e dei suoi tributari in seguito agli interventi di risanamento. Tesi di Laurea, Politecnico di Torino: 96 pp.

Ruggiu, D. \& G. Morabito. 1990. Studi sul fitoplancton effettuati negli anni 1987 e 1988, nel quadro della evoluzione a lungo termine del lago d'Orta. In: Bonacina, C., A. Calderoni \& R. de Bernardi (Eds), Ricerche limnologiche sul Lago d'Orta finalizzate al suo risanamento. Documenta Ist. ital. Idrobiol., 28: 89-100.

Ruggiu, D., A. Lugliè, A. Cattaneo \& P. Panzani. 1998. Paleoecological evidence for diatom response to metal pollution in Lake Orta (N. Italy). J. Paleolimnol., 20: 333-345.

Schuurkes, J.A.A.R. \& R. Mosello. 1988. The role of external ammonium inputs in freshwater acidification. Schweiz. Z. Hydrol., 50: 71-86.

Tartari, G.A. \& R. Mosello. 1997. Metodologie analitiche e controlli di qualità nel laboratorio chimico dell'Istituto Italiano di Idrobiologia. Documenta Ist. ital. Idrobiol., 60: $160 \mathrm{pp}$.

Tonolli, V. \& R.A. Vollenweider. 1961a. Rapporto sulle ricerche eseguite sul Lago d'Orta nel periodo dal 1959 al 1961. Pallanza, Ottobre 1961: $18 \mathrm{pp}$.

Tonolli, V. \& R.A. Vollenweider. 1961b. Le vicende del Lago d'Orta inquinato da scarichi cupro-ammoniacali. In: Atti Convegno Acque di scarico industriali. Milano, 4-7 Aprile 1960: 99-109.

van Dam, H. \& A. Mertens. 1990. A comparison of recent epilithic diatom assemblages from the industrially acidified and copper polluted Lake Orta (Northern Italy) with old literature data. Diatom Research, 5: 1-13.

Vollenweider, R. A. 1963. Studi sulla situazione attuale del regime chimico e biologico del Lago d'Orta. Mem. Ist. ital. Idrobiol., 16: 21-125. 